\title{
A Review of Retrofit Interventions for Residential Buildings in Hot Humid Climates
}

\author{
Tunmise Timothy Ayodele, Ahmad Taki, Muyiwa Oyinlola, and Bhattacharyya Subhes
}

\begin{abstract}
Buildings consume $40 \%$ of resources around the world, low energy building is fast becoming a major component of sustainable development. However, limiting the concept of low energy buildings to new builds will only undermine its effects and benefits as there are numerous existing buildings that consume uneconomical energy resources irrespective of how energy efficient the new ones are. Therefore, retrofit interventions to existing buildings is important in decreasing resource consumption and increasing energy efficiency. Some various retrofit interventions already exist towards reducing energy consumption in residential buildings but deciding on a specific retrofit intervention needs assiduous consideration. Hence, this paper focuses on the review of retrofit interventions and their energy performances. It was found amongst others that clay bricks, sand line, and pre-fabricated walls consume less energy than concrete bricks by $16 \%, 23 \%$, and $25 \%$ respectively. Electrochromic glazing system with no shading device was also found to have reduced heat gains by $53 \%-59 \%$ in winter and summer. It was concluded that further research would benefit from the combination of the various interventions to create pathways for building retrofit in hot humid climate, the pathways can be tested with a dynamic thermal simulation software for energy performance.
\end{abstract}

Index Terms - Retrofit interventions, hot humid climate, low energy, energy performance.

\section{INTRODUCTION}

Climate change has a significant effect on the ecosystem, the rise in the atmospheric temperature of the globe, intense cold and heat waves, rising ocean levels, and lot of climatic irregularities are the drivers of the climate change. [1] concluded that increase in the effect of climate change is as a result of human activities that keep releasing greenhouse gases in the atmosphere with Carbon dioxide $\left(\mathrm{CO}_{2}\right)$ having the highest concentration. Consequently, the US National Oceanic and Atmospheric Administration (NOAA) recorded June 2017 as much warmer than average conditions across much of the world's land and ocean surface. The record breaking of $0.91^{0} \mathrm{C}$ more than the average temperature for the $20^{\text {th }}$ century was recorded; this was more than the 2015 record of $0.02^{\circ} \mathrm{C}$.

Buildings play important roles in people's daily activities as they spend approximately $85 \%$ of their time indoors [2].

Manuscript received December 12, 2019; revised March 19, 2020.

Tunmise Timothy Ayodele is with Leicester School of Architecture, De Montfort University, United Kingdom (e-mail: tunmisetimothy.ayodele@dmu.ac.uk).

Ahmad Taki is with Architecture Research Institute, De Montfort University, United Kingdom (e-mail: ahtaki@dmu.ac.uk).

Muyiwa Oyinlola and Bhattacharyya Subhes are with Institute of Energy \& Sustainable Development, De Montfort university, United Kingdom (e-mail: muyiwa.oyinlola@dmu.ac.uk, subhesb@dmu.ac.uk).
One of the main functions of buildings is to provide protection against harsh outdoor weather condition which is on the increase as a result of climate change. However, buildings are the highest contributor to greenhouse gas emissions. [3] estimated that the building sector accounts for $40 \%$ of energy consumption in the world and $80 \%$ of the energy used is attributed to air conditioning systems and artificial lightning, where residential buildings typically have very high energy consumption level for cooling, the usage often amounting to approximately $60 \%$ in all household. The excessive use of air-conditioner is a concern on energy efficiency, as well as economic concern; since an increase in the demand for energy to run air-conditioners raises the energy load which also makes the utilities to burn more fossil thereby increasing the cost of energy and pollution. Also, serious concern has been raised on the quality of indoor air as a result of the use of air-conditioners [4].Cooling in residential buildings is the reason for the increase in energy consumption worldwide. It is estimated that global emissions from buildings could double by 2030 [5], but the 4th assessment report of intergovernmental panel on climate change concluded that the building sector has a significant potential of reducing energy consumption. The report suggested that with proven and available technologies, the energy consumption in buildings can be reduced by $30-50 \%$ without a significant increase in the cost of investment.

This paper therefore provides a review of retrofit interventions, and renewable energy systems integrated to existing buildings in existing literature. It provides opportunity for future research into the impacts of retrofit interventions on thermal comfort and cost of energy. The review adopts academic studies and publications that are relevant to the potential of integrating retrofit interventions in residential buildings in hot humid climate, the results from the literature review is presented in categories of building envelopes and renewable energy as interventions towards reducing energy consumption and corresponding reduction in carbon emission in hot humid climates.

\section{RETROFIT INTERVENTIONS AND THE KEY INDICATORS IN HOT HUMID CLIMATES}

The most influential climatic factors in hot humid climates are high temperature due to solar radiation and high humidity due to rainfall. Therefore, to control high indoor temperature some solution based on three philosophy of prevention, delay, and removal of solar radiation have been widely applied [6]-[8]. Another recommendation that is climatic responsive is the 'Umbrella Concept' used for building roof with deep eaves, it protects driving rains and serves as a sun shading 
device [9], [10]. Other approaches incorporating natural ventilation is emphasized to improve thermal comfort, good health, and wellbeing of residents while reducing the cooling loads. Even though most of the strategies from previous studies used in conservation of energy are not new, the challenges of incorporating them into existing building is prominent such that they combine new ideas in science and technology and disagree in principle.

The key indicators for an effective retrofit strategy are reducing energy consumption while maintaining thermal comfort, improving architectural quality, achieving limited impact of carbon emission on the globe, and making the expected cost of a retrofit intervention worthwhile. However, some of these indicators often contradict in principle. A review of retrofit technologies suggested that less cost investment is required to retrofit building services and systems while achieving more environmental benefits than using renewable energy technologies [11]. Furthermore, towards an optimum retrofit intervention process, some conflict of interest has been identified such as, energy use improvement against architectural quality [12]. Therefore, to find an optimum retrofit package is a fusion that needs to be critically reviewed.

\section{BUILDING ENVELOPE}

Building envelopes comprise of structural materials and finishes that separate inside from the outside, the enclosed space must balance requirement for ventilation and daylight while providing thermal comfort [13]. The building envelope is often described as a function of its heat flow which is known as U-Value [14]. The U-Values are available in building standards for various materials.[15] and [16] reported similar results where indoor temperatures of up to $4^{\circ} \mathrm{C}$ and $7^{\circ} \mathrm{C}$ lower than the outdoor temperatures were obtained using a variety of materials for the building envelope in hot humid and equatorial climates of Israel and Kenya respectively.

Similarly, [17] examined the effectiveness of building envelope in free flow building using low, medium, and high level of mass with the same heat loss coefficients for three buildings in hot humid climate of Sala, San Diego. Indoor temperature of $24.5^{\circ} \mathrm{C}$ and outdoor temperature of $34^{\circ} \mathrm{C}$ were recorded on the hottest summer day of the research for the high mass building. However, [15] concluded that it is not recommended to use thermal mass with night ventilation as a passive cooling strategy in hot-humid climate such as Florida because the diurnal temperature difference between the day and the night is not enough to dissipate heat gains. This suggests that ventilation strategy other than natural ventilation needs to be introduced.

Previous study carried out in Saudi Arabia had a case study of 6 homes, 3 typical detached houses and 3 typical apartments for retrofit through the building envelope. Insulation was introduced to the wall, roof and triple glazing was added to prevent massive direct solar heat transfer, external shading and landscaping to prevent heat gain [18]. This study was carried out to know the factors that influence energy usage in residential buildings.
The result suggests that the building envelope is an important factor that influence the amount of energy used in a building. With energy consumption reduced by $15 \%$ and $34 \%$ for each property it also demonstrates that retrofit intervention is peculiar to the local climatic condition as shown in Fig. 1 below. The building envelope comprises of several element which are discussed below.

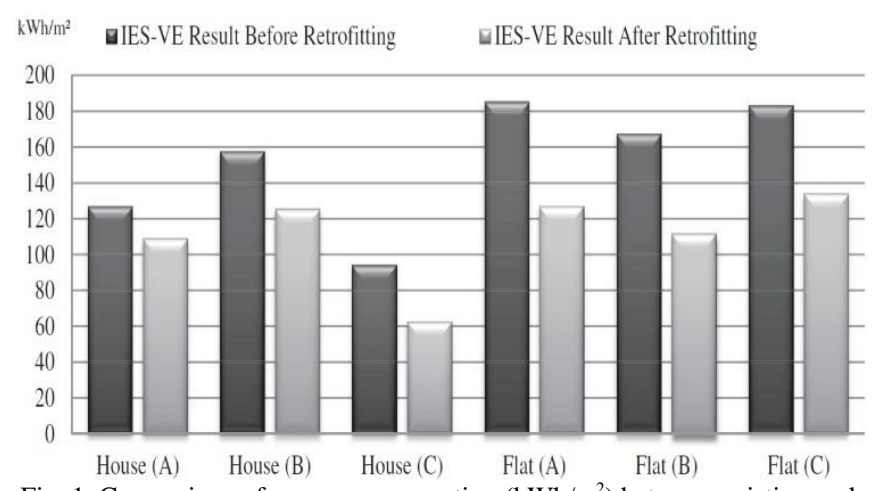

Fig. 1. Comparison of energy consumption $\left(\mathrm{kWh} / \mathrm{m}^{2}\right)$ between existing and after simulation Source: [18].

\section{WALLS AND THERMAL MASS}

An attempt to carry out retrofit by optimising the building envelope would result in reducing energy usage in buildings. Previous studies identified walls as one of the contributors to energy increase, some of which further focused on the thermal mass other than materials used for the wall construction [19]. Thermal mass is the ability of the material to absorb and store heat energy. High density materials such as bricks and concrete require high amount of heat energy to change their temperatures. Such materials are referred to as having high thermal mass due to their capacity of heat storage, but low thermal mass materials are normally light weight such as timber. Thermal mass materials moderate indoor temperature by regulating day to night temperature extremes. According to [19] thermal mass is highly effective where there is high temperature difference between the day and night outdoor temperatures.

Furthermore, the thermal quality of the wall through insulation with high thermal resistance and low thermal bridges was tested from previous studies. This was done with various types of masonry materials from four samples of clay bricks, concrete sand line bricks, and prefabricated walls with $0-50 \mathrm{~cm}$ thickness. The result concluded that clay bricks consumed less energy by $16 \%$ compared to concrete bricks, the sand line $23 \%$, and $25 \%$ with prefabricated walls [20].

\section{INSULATION}

Furthermore, the use of insulation on different levels of thickness of the wall and the location was investigated with a focus on concrete blocks and clay bricks [19]. The results showed that concrete blocks require more insulation compared to clay blocks. Insulations are incorporated into the building envelopes to retard heat flow in and out of the building. This is vital as a barrier to flow of heat in maintaining comfort in the building while reducing energy consumption. If adequately designed, an insulated building 
gives comfort throughout the year and reduces the energy consumption due to cooling by up to $50 \%$, this also in turn reduces carbon emission.

The value that shows the level of performance of insulation is referred to as the R-Value. A higher R-Value indicates a better performance. It is mostly fitted in the roof, walls or floors to maintain comfort and reduce energy consumption. However, the suitability of the level of insulation is determined by the type of climate and specific location [21]. For instance, a common type of reflective insulation material (aluminium foil layered onto plastic or paper) is commonly known as radiant barrier. Although they are used in façade and floors, they are commonly used in roofing insulation [22]. [21] concluded that radiant barriers are highly effective when directly installed under metal roof sheeting and can also prevent radiant heat gain into the roof space by up to $95 \%$. Although insulation is found to be the most effective when both bulk and reflective insulations are combined [Fig. 2], the installation for naturally ventilated buildings differ from air-conditioned ones. [21] concluded that the roof insulation is more effective when combined with ridge and eave vents because east and west facing walls are difficult to shade with overhangs.

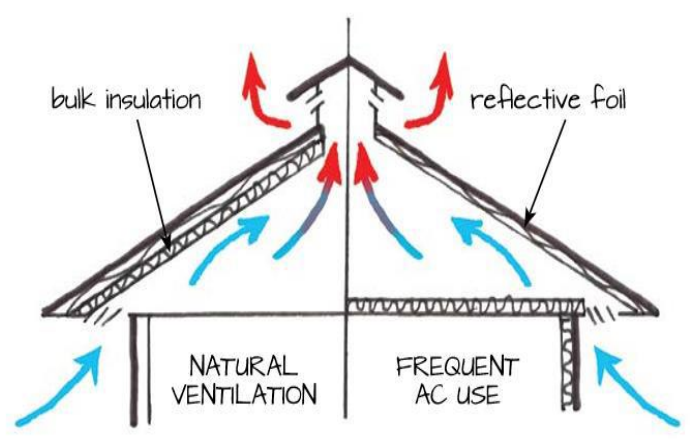

Fig. 2. Installation of combined bulk and reflective insulation. Source: [21].

\section{RoOF}

The roof is also another part of the building envelope that determines the performance of energy. The roof of a building offers significant solution by conserving energy for indoor cooling [23]. Previous studies considered design variables for low energy buildings, to find out the effective roof type and material that reduces energy consumption in Abuja Nigeria using simulation. The results indicated that insulated roofs have better energy performance compared to an un-insulated roof. The predictions suggested $25 \%$ reduction using $4.5 \mathrm{~cm}$ of Poly-ethane insulation [24].

A similar simulation result carried out in Saudi Arabia showed $32 \%$ reduction using $5.0 \mathrm{~cm}$ of moulded polystyrene insulation and $27 \%$ for extruded [25]. For hot humid climates, the roof is mostly affected by solar radiation because the angle of solar radiation is overhead throughout the year because the incidence angle is close to normal in the peak periods of the day [26]. Therefore, ventilation of the roof cavity by erecting roof and eave vents reduces heat build-up and cools the building [21].

Several advantages of green roofs have been demonstrated in research [27]. They provide insulation due to the soil and evapotranspiration which keeps the roof cool despite solar radiation [23]. Green roofs serve as thermal insulation thus reducing energy consumption while maintaining thermal comfort. [28] also suggested that incorporation of green roof improves the quality of water runoff.

However, complexity in the installation and maintenance of green roof has resulted in consideration of some simpler alternatives. A change in colour of the roof to a lighter colour allows for reduction in energy demand due to the efficiency of lighter colours in reflecting sunlight. White roof will be cooler during hottest period thus reducing the energy demand to cool the building because of its high reflectance quality [29]. The illustrative case study in Fig. 3 shows the effect of change in roof colour for a residential building in Australia. The application of reflective white paint reduced the roof temperature by $20 \mathrm{~K}$ on the afternoon of the second day, and as well reduced the interior air temperature relative to the ambient temperature. The interior temperature was $2.1 \mathrm{~K}$ above the ambient before application of the white paint and was $0.8 \mathrm{~K}$ above the ambient after the painting.

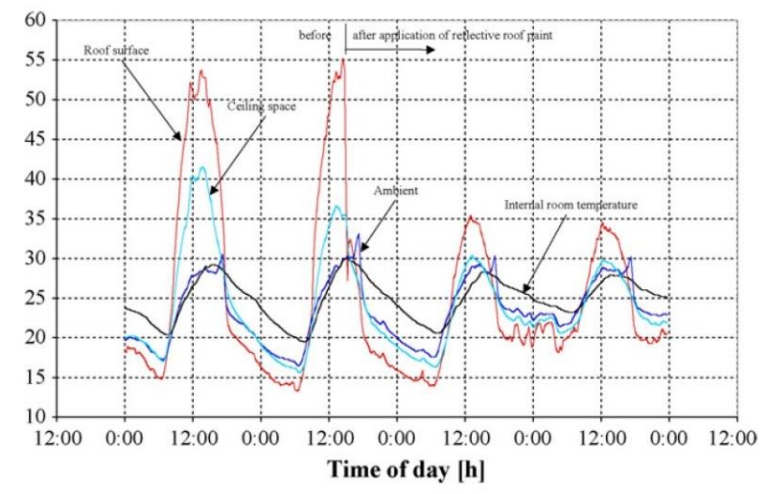

Fig. 3. Temperature measurement of 4 days before and after applying white reflective paint Source:[30]

A significant reduction in energy consumption can be achieved if a light-coloured roof is used for retrofits. Previous numerical simulation argued that a light-coloured roof reduces operative temperature and solar heat gain by $30 \%$ when compared with a dark roof. The energy consumed when compared, is like energy consumed if a cooling system is installed [30]. Roofs that are white can improve comfort and yet reduce energy consumption.

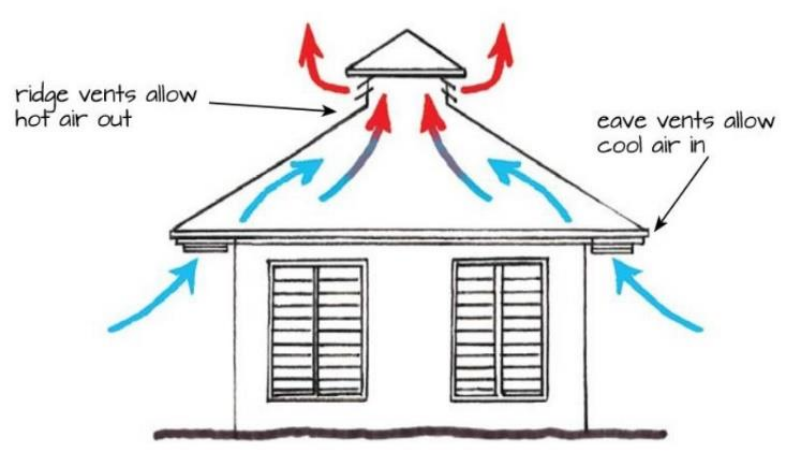

Fig. 4. Combination of eave and roof vents reduces heat build-up. Source: [21].

[31] further analysed the thermal performance of ventilated roof by calculating the amount of exhausted heat. The study showed a difference in temperature of $37.5^{\circ} \mathrm{C}$ 
between the ventilated and non-ventilated cavity. [21] concluded that the ventilation incorporated in the roof could prevent accumulated heat and therefore reduces the cooling load of the building as shown in [Fig. 4].

\section{WINDOWS}

Windows connect the inside to the outside. It is also an important factor that impact energy use in buildings. Windows are used for ventilation, lightning and viewing purposes. So, its size needs to be considered for the purpose of solar radiation control [32]. Previous investigation on the impact of window construction materials with a focus on the type of glazing was carried out in Riyadh and Dhahran which concluded that using appropriate glazing produces significant energy reduction in hot climates [19]. Double glazing is commonly used for external windows, but the thermal performance of such window is determined by the type of glass and the introduction of thermal breaker in the system [33].

Studies further examined improving the performance of double-glazed windows by filling the gap between the panes of glazing with gas, use of low-emittance coating on glass, and inserting a thermal breaker made of polyurethane. [33] concluded that insulation with broken aluminium and thick-walled plastic will satisfy the required minimum temperature. Triple glazed window was however identified as a veritable tool for energy saving, moreover they maintain adequate levels of day-lighting in buildings.

Recommendations for window sizes in hot humid climates vary [6]; [34]. Buildings with small windows are common practice in arid zones to reduce solar radiation at the expense of indoor lightning where large windows are used. Protection from solar radiation becomes important [35]. Minimizing the size of windows facing south and increasing the size of the windows facing north have significant effects on energy performance and improve brightness [36]. [37] extended previous research by introducing shading to the windows, the research was analysis was carried out by using simulation tools and detailed weather data for Phoenix, Arizona in the United States representing a hot and dry climate, four different alternatives were generated for same model in the simulation software, the calibration of the software is shown in Table I below.

TABLE I: BUILDING ALTERNATIVES DIMENSIONS AND SHADING CONDITION

\begin{tabular}{|c|c|c|c|}
\hline \multicolumn{4}{|c|}{ [37] } \\
\hline Alternative & $\begin{array}{l}\text { Dimen- } \\
\text { sions (m) }\end{array}$ & $\begin{array}{l}\text { Floor } \\
\text { area } \\
\left(\mathbf{m}^{2}\right)\end{array}$ & Shading condition \\
\hline Altemative (1) & $72.0 \times 36.0$ & 2592.0 & $\begin{array}{l}\text { - Double-glazed windows } \\
\text { - No shading devices }\end{array}$ \\
\hline Altemative (2) & $72.0 \times 36.0$ & 2592.0 & $\begin{array}{l}\text { - Double-glazed windows } \\
\text { - Fixed shading devices } \\
\text { (overhangs) }\end{array}$ \\
\hline Alternative (3) & $72.0 \times 36.0$ & 2592.0 & $\begin{array}{l}\text { - } 1.5 \mathrm{~m} \text { projection } \\
\text { - } \quad \text { Fouble-glazed windows } \\
\text { Fixed shading devices } \\
\text { (overhangs and side fins) } \\
\text { - } 1.0 \mathrm{~m} \text { projection }\end{array}$ \\
\hline Alternative (4) & $72.0 \times 36.0$ & 2592.0 & $\begin{array}{l}\text { - Electrochromic glazing } \\
\text { system } \\
\text { - No shading devices }\end{array}$ \\
\hline
\end{tabular}

The results for the simulation in Table $\mathbf{I}$ above is shown in
Fig. 5 below, it was concluded that alternative 4 shows have the best performance among the tested alternatives based on the reduction in solar heat gains of approximately 53-59\% in both winter and summer.

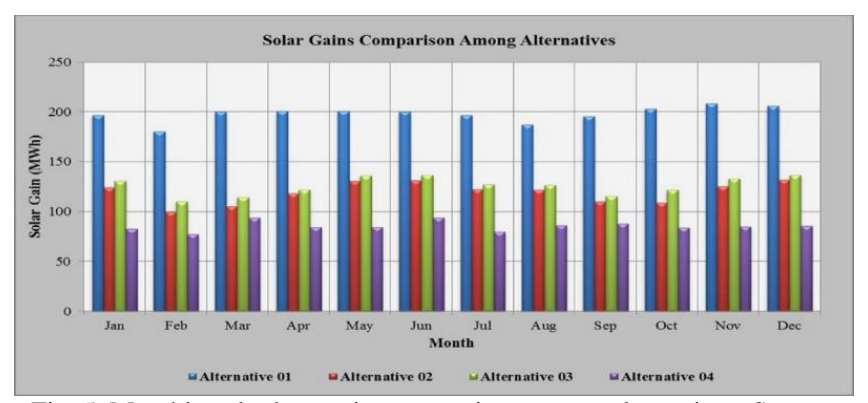

Fig. 5. Monthly solar heat gains comparison among alternatives. Source: [37].

TABLE II: SUMMARY OF RETROFIT INTERVENTIONS IN HOT HUMID

\begin{tabular}{|c|c|c|c|c|c|c|}
\hline \multicolumn{7}{|c|}{ Climate } \\
\hline Element & & Retrofit Strategy & Methodology & Findings & Location & Reference \\
\hline Roof & & $\begin{array}{l}\text { Coating roofs white } \\
\text { Use of reflective roofs } \\
\text { The albedo of the roof } \\
\text { was changed from } \\
0.18 \text { to } 0.73 \text { in a } \\
\text { residential building }\end{array}$ & Experiment & $\begin{array}{l}\text { - Reduction of energy use } \\
\text { between } 10 \% \text { and } 50 \% \\
\text { - Savings of } 2.2 \mathrm{kWh} \text { day } \\
\text { on energy required for } \\
\text { cooling was achieved }\end{array}$ & $\begin{array}{l}\text { Atlanta, } \\
\text { Chicago, } \\
\text { USA. }\end{array}$ & [43] \\
\hline $\begin{array}{l}\text { Roof, } \\
\text { wall, and } \\
\text { window }\end{array}$ & & $\begin{array}{l}\text { Use of efficient } \\
\text { insulation in wall, } \\
\text { roof, door, and floor. } \\
\text { Efficient insulated } \\
\text { double or triple } \\
\text { glazing to prevent } \\
\text { massive direct solar } \\
\text { heat transfer. } \\
\text { External shading and } \\
\text { landscaping }\end{array}$ & Simulation & $\begin{array}{l}\text { The annual energy } \\
\text { consumption is reduced } \\
\text { by between } 15 \% \text { and } \\
34 \% \text { for each property }\end{array}$ & $\begin{array}{l}\text { Riyadh, } \\
\text { Saudi } \\
\text { Arabia. }\end{array}$ & [18] \\
\hline Roof & & $\begin{array}{l}\text { Application of cool } \\
\text { roof coatings } \\
\text { Increase the roof solar } \\
\text { reflectance } \\
\text { Change in roof colour } \\
\text { to reflective white for } \\
2 \text { days }\end{array}$ & Simulation & $\begin{array}{l}\text { - Increase in roof solar } \\
\text { reflectance by } 0.65 \text { from } \\
\text { application of a cool } \\
\text { coating, reduces loads } \\
\text { by } 8-48 \mathrm{k} W \mathrm{k} / \mathrm{m} 2 \\
\text { - Reduced the hours of } \\
\text { discomfort by } 9-100 \% \\
\text { - Reduced maximum } \\
\text { temperature by } 1.2 \text { - } \\
3.7^{\circ} \mathrm{C}\end{array}$ & $\begin{array}{l}\text { Cairo, } \\
\text { Egypt. } \\
\text { New Delhi, } \\
\text { India. }\end{array}$ & [4] \\
\hline Roof & & & Experiment & $\begin{array}{l}\text { Roof temperature } \\
\text { reduced by about } 20 \mathrm{~K} \\
\text { on the aftemoon of the } \\
\text { second day. } \\
\text { Room temperature was } \\
\text { lowered by } 1.3 \mathrm{~K} \\
\text { - Average ambient and } \\
\text { interior air temperature } \\
\text { changed from } 21.8 \text { and } \\
23.9^{\circ} \mathrm{C} \text { to } 23.2 \text { and } \\
24.0^{\circ} \mathrm{C} \text { respectively }\end{array}$ & $\begin{array}{l}\text { Tounsville, } \\
\text { Australia }\end{array}$ & [30] \\
\hline $\begin{array}{l}\text { Roof, } \\
\text { wall, and } \\
\text { window }\end{array}$ & & $\begin{array}{l}\text { Walls with an } \mathrm{R} \text {-value } \\
\text { of } 1.96 \mathrm{~m} 2 . \mathrm{K} / \mathrm{W} \text { was } \\
\text { introduced. } \\
\text { Roofs with an } \mathrm{R} \text { - } \\
\text { value of } 5.88 \mathrm{~m} 2 . \mathrm{K} / \mathrm{W} \\
\text { was introduced } \\
\text { Windows with a U. } \\
\text { value of } 3.321 \\
\text { W/ } \mathrm{m}^{2} . \mathrm{K} \text { was } \\
\text { introduced } \\
\text { High performance } \\
\text { double glazing, and } \\
0.35 \mathrm{ACH} \text { air } \\
\text { infiltration }\end{array}$ & Simulation & $\begin{array}{l}\text { Total energy } \\
\text { consumption was } \\
\text { reduced by } 15 \% \text { and } \\
18 \% \text { for poorly } \\
\text { insulated design in } \\
\text { Dhahran and Riyadh } \\
\text { respectively. } \\
\text { Total energy } \\
\text { consumption was } \\
\text { reduced by } 38 \% \text { and } \\
32 \% \text { for well insulated } \\
\text { design in Dhahran and } \\
\text { Riyadh respectively. }\end{array}$ & $\begin{array}{l}\text { Dhahran and } \\
\text { Riyadh, } \\
\text { Saudi Arabia }\end{array}$ & [31] \\
\hline
\end{tabular}

Although protection to windows can be achieved by simple shading using vegetation, the lateral progression of modern building tends to reduce this potential. Therefore, shading elements in form of horizontal or vertical shelves placed inside or outside can be used [38]. This shading device according to [39] can be flexible modules to enable adjustments, optimize day-lighting, and energy savings potentials due to cooling loads as a result of heat gains.

The effect of different shading approaches on inside temperature and solar heat gains protection were investigated by using reveals, vertical fins, and overhangs. They showed that window reveals were best for reducing solar gains and reducing internal temperatures, followed by overhangs, and 
vertical fins respectively [40]. However, determining the appropriate shading for buildings remain a complicated process due to previous knowledge and understanding of the sun movement, timing, and positioning in a location [41] . Also, investigation on the importance of low emittance value was carried out in three different climatic conditions, using two types of buildings (sensitivity for small changes in the emittance). The research concluded that reducing thermal emittance by $2 \%$ to $3 \%$ and the solar radiation energy transmittance by $2 \%$ to $3 \%$, the energy performance of external windows will be poor if the residential building is south facing [42]. A summary of some retrofit strategies in a typical hot climate is summarised in [Table II]

\section{RENEWABLE ENERGY}

To further reduce energy consumption in buildings after exhausting the proper retrofitting of the building envelope, cooling system that is highly efficient with low capacity can then be installed. Significant progress has been made in the area of renewable energy such as: wind energy and solar radiation in form of photovoltaic or thermal application [43]. However, [44] argued that the recent trend involves distribution renewable generation, energy storage possibilities, and demand-side load management. They concluded that adopting multi-generation system to produce renewable energy will result in improved energy performance.

[45] observed that there is a rapid increase in the installation of building-integrated photovoltaics because many nations are establishing some goals towards reduction of energy consumption. To achieve these goals, existing buildings are expected to incorporate energy efficiency, savings, and optimal use of technologies such as photovoltaic to generate energy naturally. Although photovoltaic technology has great benefits for people, high penetration can cause energy quality in the electricity network [46]. This form of renewable energy is applicable and more efficient in hot climates that have a huge amount of solar radiation.

A study analysed multi-family houses in different locations in Brazil with an aim to discover the impact of integrated photovoltaics system on energy consumption. It was concluded that a large amount of energy can be generated through vertical facades [47]. Introducing the photovoltaic system on a roof top or the use of other renewable energy bridges the gap between generation and consumption of energy to the extent of achieving a zero-energy building [48]. A photovoltaic panel according to [49] can also improve the aesthetic value of a building when introduced in its façade. Photovoltaic cells work with high efficiency and have a significant impact on the thermal and electrical efficiency of a building. It was further argued that photovoltaic cells with a supporting structure is cost effective it can be made of low-cost material without reducing its performance [50].

Also, wind energy is a form of natural energy. Significant innovations in wind energy technology have increased the potential of energy generation through wind turbines [51]. However, there are arguments opposing wind projects, due to issues surrounding the visual landscape and noise [52]. Wind turbine technology is said to be too visible and disruptive due to its noise [53]. This technology has been found viable in countries with excess wind energy but the level of acceptance of this technology by people who live close to the location is very low. [54].

\section{CONCLUSION}

This review paper revealed that low energy retrofit involves reducing energy needed in a building while maintaining thermal comfort as well as reducing its impact on the environment in terms of carbon emission. A review of existing studies was carried out relative to evaluation of significant know-how and techniques for retrofitting in hot humid climate, existing literatures on energy performance and retrofit interventions for hot humid climatic conditions. Existing work showed that retrofit processes are more effective when integrated into building envelope, although the roof intervention was significant, the most effective and efficient intervention was found to be the electrochromic glazing system with no shading which reduces heat gain by $53 \%-59 \%$ in winter and summer. Future research would benefit from creating several pathways through the combination of various retrofit interventions for hot humid climates. Future work could also test these pathways for their respective energy performance by using dynamic thermal simulation software to demonstrate the feasibility of adopting the combination of the pathways towards a Net-zero energy consumption in residential buildings for hot humid climate.

\section{CONFLICT OF INTEREST}

The authors declare no conflict of interest

\section{AUTHOR CONTRIBUTIONS}

Ayodele T.T conducted the in-depth review research, Taki A.H was responsible for $40 \%$ of the article search and scheming, Oyinlola M.A was responsible for $20 \%$ of the article search and scheming, Bhattacharyya, Subhes proof read all findings at several point, Ayodele T.T wrote the paper, Taki A.H and Bhattacharyya, Subhes read the paper and gave feedbacks and correction before and after the peer review process. Oyinlola M.A supervised the referencing through RefWorks in collaboration with Ayodele T.T. All authors had approved the final version

\section{REFERENCES}

[1] O. Golubchikov and A. Badyina, "Sustainable housing for sustainable cities: A policy framework for developing countries," UN Habitat, 2012.

[2] R. Plank, Sustainable Building Construction for Structural Engineers, 2005.

[3] R. F. Rupp, N. G. Vásquez, and R. Lamberts, “A review of human thermal comfort in the built environment," Energy \& Buildings, vol. 105, pp. 178-205, Oct 15, 2015.

[4] A. Synnefa, M. Santamouris, and H. Akbari, "Estimating the effect of using cool coatings on energy loads and thermal comfort in residential buildings in various climatic conditions," Energy \& Buildings, vol. 39, no. 11, pp. 1167-1174, 2007.

[5] S. Solomon, "Climate change 2007: The physical science basis," 2007.

[6] M. Fry and J. Drew, Architecture and the Environment, London: Allen \& Unwin, 1976.

[7] P. Gut and D. Ackerknecht, "Climate responsive building," St. Gallen: Skat-Verl, 1993. 
[8] D. Ossen, R. Majid, and M. Ahmad, "Tropical design principles for comfortable indoor climate," 2008.

[9] M. A. O. Oyeniyi, "Architectural design and climate - An overview," 1997.

[10] C. O. Osasona, "Heritage architecture as domestic space: A tale of three buildings in ile-ife, nigeria," International Journal of Sustainable Development and Planning, vol. 10, no. 1, pp. 42-65, Feb. 28, 2015.

[11] M. Rabani, H. B. Madessa, and N. Nord, "A state-of-art review of retrofit interventions in buildings towards nearly zero energy level," Energy Procedia, vol. 134, pp. 317-326, 2017.

[12] D. Kolokotsa, C. Diakaki, E. Grigoroudis, G. Stavrakakis, and K. Kalaitzakis, "Decision support methodologies on the energy efficiency and energy management in buildings," Advances in Building Energy Research, vol .3, no. 1, pp. 121-146, Jan 1, 2009.

[13] R. M. Reffat, "Sustainable construction in developing countries," 2004.

[14] J. Yu, C. Yang, L. Tian, and D. Liao, "A study on optimum insulation thicknesses of external walls in hot summer and cold winter zone of china," Applied Energy, vol. 86, no. 11, pp. 2520-2529, 2009.

[15] E. Shaviv et al., "Thermal mass and night ventilation as passive cooling design strategy," Renewable Energy, vol. 24, no. 3, pp. 445-452, 2001.

[16] D. M. Ogoli, "Predicting indoor temperatures in closed buildings with high thermal mass," Energy \& Buildings, vol. 35, no. 9, pp. 851-862, 2003.

[17] B. Givoni, "Effectiveness of mass and night ventilation in lowering the indoor daytime temperatures. part I: 1993 experimental periods," Energy \& Buildings, vol. 28, no. 1, pp. 25-32, 1998

[18] N. A. Aldossary, Y. Rezgui, and A. Kwan, "Domestic energy consumption patterns in a hot and arid climate: A multiple-case study analysis," Renewable Energy, vol. 62, pp. 369-378, 2014.

[19] M. A. Abdelrahman, S. A. M. Said, and A. Ahmad, "A comparison of energy consumption and cost-effectiveness of four masonry materials in saudi arabia," Energy, vol. 18, no. 11, pp. 1181-1186, 1993.

[20] S. A. Al-Sanea, M. F. Zedan, and S. N. Al-Hussain, "Effect of thermal mass on performance of insulated building walls and the concept of energy savings potential," Applied Energy, vol. 89, no. 1, pp. 430-442, 2012.

[21] Cairns, Annual report / cairns regional council, Queensland, Australia: 2014.

[22] C. Escudero, K. Martin, A. Erkoreka, I. Flores, and J. M. Sala, "Experimental thermal characterization of radiant barriers for building insulation," Energy \& Buildings, vol. 59, pp. 62-72, Apr 2013.

[23] M. Zinzi and S. Agnoli, "Cool and green roofs. An energy and comfort comparison between passive cooling and mitigation urban heat island techniques for residential buildings in the mediterranean region," Energy \& Buildings, vol. 55, pp. 66-76, 2012.

[24] A. I. Mu'azu, "Sustainable design strategy: Assessment of the impact of design variables on energy consumption of office buildings in abuja, nigeria," ProQuest Dissertations Publishing, 2015.

[25] S. A. Al-Sanea, "Thermal performance of building roof elements," Building and Environment, vol. 37, no. 7, pp. 665-675, 2002.

[26] C. Kabre, "A new thermal performance index for dwelling roofs in the warm humid tropics," Building and Environment, vol. 45, no. 3, pp. 727-738, 1976.

[27] A. M. Coutts, E. Daly, J. Beringer, and N. J. Tapper, "Assessing practical measures to reduce urban heat: Green and cool roofs," Building and Environment, vol. 70, pp. 266-276, 2013.

[28] A. J. Bates, J. P. Sadler, and R. Mackay, "Vegetation development over four years on two green roofs in the UK," Urban Forestry \& Urban Greening, vol. 12, no. 1, pp. 98-108, 2013.

[29] American Society of Heating, Refrigerating and Air-Conditioning Engineers - ASHRAE, "ASHRAE standard," ASHRAE standard, vol. 2007, p. 52, 2007.

[30] H. Suehrcke, E. L. Peterson, and N. Selby, "Contents," Energy \& Buildings, vol. 61, pp. iv-v, 2013.

[31] S. N. Al-saadi and I. M. Budaiwi, "Performance-based Envelope design for residential buildings in hot Climates SAAD group, design office, AL-khobar 31952, P. O. box 3250, Saudi Arabia Architectural Engineering Department, King Fahd University of Petroleum and Minerals, dhahran 3126," Residential System, pp. 1726-1733, 2007.

[32] N. Baker and K. Steemers, Daylight Design of Buildings, London: James \& James, 2002.

[33] S. Song, K. Song, J. Jo, M. Yeo, and Y. Kim, "Evaluation of inside surface condensation in double glazing window system with insulation spacer: A case study of residential complex," Building and Environment, vol. 42, no. 2, pp. 940-950, 2007.

[34] O. H. Koenigsberger, Manual of Tropical Housing and Building, London: Longman.
[35] A. Al-Temeemi, "Climatic design techniques for reducing cooling energy consumption in kuwaiti houses," Energy \& Buildings, vol. 23, no. 1, pp. 41-48, 1995.

[36] M. Persson, A. Roos, and M. Wall, "Influence of window size on the energy balance of low energy houses," Energy \& Buildings, vol. 38, no. 3, pp. 181-188, 2006.

[37] A. Aldawoud, "Conventional fixed shading devices in comparison to an electrochromic glazing system in hot, dry climate," Energy \& Buildings, vol. 59, pp. 104-110, 2013.

[38] K. Ko et al., "Thermal performance in building without shading devices," 2006.

[39] M. Bessoudo, A. Tzempelikos, A. K. Athienitis, and R. Zmeureanu, "Building and environment,", vol. 45, no. 6, p. 132, 2017.

[40] A. Offiong and A. U. Ukpoho, "External window shading treatment effects on internal environmental temperature of buildings," Renewable Energy, vol. 29, no. 14, pp. 2153-2165, 2004.

[41] S. Szokolay, "Solar geometry. paper presented at the passive and low energy architecture international, louvain-la-neuve, belgium," Louvain-la-Neuve, Belgium.

[42] J. Karlsson and A. Roos, "Annual energy window performance vs. glazing thermal emittance - The relevance of very low emittance values," Thin Solid Films, vol. 392, no. 2, pp. 345-348, 2001.

[43] F. Manzano-Agugliaro, A. Alcayde, F. G. Montoya, A. Zapata-Sierra, and C. Gil, "Scientific production of renewable energies worldwide: An overview," Renewable and Sustainable Energy Reviews, vol. 18, pp. 134-143, 2013.

[44] G. Chicco and P. Mancarella, "Distributed multi-generation: A comprehensive view," Renewable and Sustainable Energy Reviews, vol. 13, no. 3, pp. 535-551, 2009

[45] V. Delisle and M. Kummert, "A novel approach to compare building-integrated photovoltaics/thermal air collectors to side-by-side PV modules and solar thermal collectors," Solar Energy, vol. 100, pp. $50-65,2014$

[46] G. Mokhtari, G. Nourbakhsh, F. Zare, and A. Ghosh, "Overvoltage prevention in LV smart grid using customer resources coordination," Energy \& Buildings, vol. 61, pp. 387-395, Jun 2013.

[47] M. Ordenes, D. L. Marinoski, P. Braun, and R. Rüther, "The impact of building-integrated photovoltaics on the energy demand of multi-family dwellings in brazil," Energy \& Buildings, vol. 39, no. 6, pp. 629-642, 2007.

[48] K. F. Fong and C. K. Lee, "Towards net zero energy design for low-rise residential buildings in subtropical hong kong," Applied Energy, vol. 93, pp. 686-694, 2012.

[49] M. M. Probst and C. Roecker, "Towards an improved architectural quality of building integrated solar thermal systems (BIST)," Solar Energy, vol. 81, no. 9, pp. 1104-1116, 2007.

[50] T. N. Anderson, M. Duke, G. L. Morrison, and J. K. Carson, "Performance of a building integrated photovoltaic/thermal (BIPVT) solar collector," Solar Energy, vol. 83, no. 4, pp. 445-455, 2009.

[51] J. Swofford and M. Slattery, "Public attitudes of wind energy in texas: Local communities in close proximity to wind farms and their effect on decision-making," Energy Policy, vol. 38, no. 5, pp. 2508-2519, 2010

[52] J. D. Groothuis, P. A. Groothuis, and J. C. Whitehead, "Green vs. green: Measuring the compensation required to site electrical generation windmills in a viewshed," Energy Policy, vol. 36, no. 4, pp. 1545-1550, 2008.

[53] M. J. Pasqualetti, P. Gipe, and R. W. Righter, "Wind power in view: Energy landscapes in a crowded world," San Diego: Academic Press, 2002.

[54] C. R. Warren, C. Lumsden, S. O'Dowd, and R. V. Birnie, "'Green on green': Public perceptions of wind power in scotland and ireland," Journal of Environmental Planning and Management, vol. 48, no. 6 , pp. 853-875, Nov. 1, 2005 .

Copyright $\odot 2020$ by the authors. This is an open access article distributed under the Creative Commons Attribution License which permits unrestricted use, distribution, and reproduction in any medium, provided the original work is properly cited (CC BY 4.0).

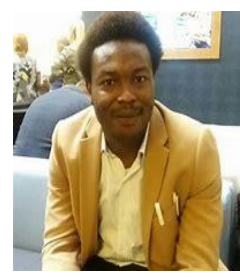

Tunmise Ayodele is a PhD candidate at De Montfort University, Leicester United Kingdom. Working towards a $\mathrm{PhD}$ in low energy retrofits of residential building in hot humid climate. He holds a BSc in Architecture, PGD in Architectural design and practices, MSc in Architecture and sustainability. He is experienced in the development and delivery of academic content both at Undergraduate and 
Postgraduate Level. He has a proven knowledge and record of research and teaching around Construction, Architecture, and sustainability concepts, such as low energy buildings, retrofitting, urbanization, design and practices, landscaping, cultural and contextual studies, measurements and related areas that enhance the practice and productivity in the workplace. His has done some work on robust design and supervision of road and building construction, develop and ensure environmental impact analysis, research and implementation of affordable housing schemes for low income households.

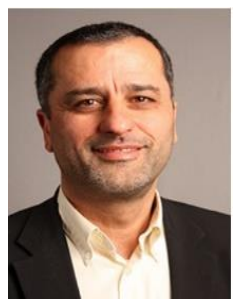

Ahmad Taki is a director of the Architecture Research Institute, a professor of building performance and sustainability, and a senior fellow of Higher Education Academy (HEA) at De Montfort University Leicester United Kingdom. $\mathrm{He}$ is experienced in design strategies and building physics to promote and encourage sustainability, human thermal interaction with the built environment, and computer modelling. He is a member of EPSRC College for peer review of research proposals. He is an invited author of 'Heat Transfer' section of the CIBSE Design Guide and has given overseas presentations on his work related to human thermal environment field.

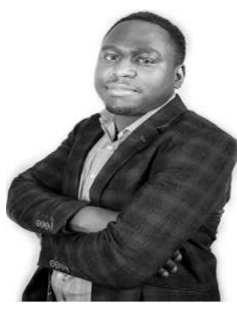

Muyiwa Oyinlola is an associate professor (engineering for sustainable development) and chartered engineer who is committed to engineering sustainable solutions for low- and middle-income countries. He holds a B.Eng. in mechanical engineering, MSc in renewable energy engineering and $\mathrm{PhD}$ in sustainable thermal energy. One of the main areas of his research focusses on building capacity of local skills to engineer and use local materials for tackling global challenges. His work places particular emphasis on identifying and integrating socio-cultural considerations required for the long-term success of engineering projects. Some of his recent research projects in this area include building capacity for sustainable homes and developing processes and products that promote upcycling and recycling of plastics in low income communities.

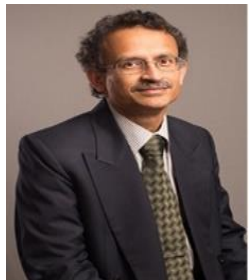

Subhes C. Bhattacharyya is an internationally renowned specialist of energy for international development with more than 30 years of experience in global energy-environment issues, He specialises in energy, regulatory and environmental studies with a focus on developing country energy systems. He has extensively investigated energy access issues in South Asia and Sub-Saharan Africa since 2002 and has led award-winning research in this area through funded projects. $\mathrm{He}$ has also extensively worked on energy secto management issues such as energy sector regulation and restructuring in developing countries, and policy issues related to energy security, climate change, natural resource utilisation and sustainable development. 